\title{
Heavy Metals In Surface Sediments Of The Intertidal Thai Binh Coast, Gulf of Tonkin, East Sea, Vietnam: Distribution, Accumulation, And Contamination Assessment
}

\author{
Lim Thi Duong \\ Vietnam Academy of Science and Technology \\ Bac Quang Nguyen ( $\sim$ quangbac1993@gmail.com ) \\ Vietnam Academy of Science and Technology https://orcid.org/0000-0003-2663-9710 \\ Cham Dinh Dao \\ Vietnam Academy of Science and Technology \\ Nhiem Ngoc Dao \\ Vietnam Academy of Science and Technology Institute of Materials Science \\ Huong Thi Lan Nguyen \\ Vietnam Academy of Science and Technology \\ Thuy Thi Huong Nguyen \\ Vietnam Academy of Science and Technology \\ Chi Thi Ha Nguyen \\ Vietnam Academy of Science and Technology Institute of Materials Science \\ Dien Cong Duong \\ Vietnam Academy of Science and Technology

\section{Ngo Nghia Pham} \\ VNU-HUS: VNU University of Science
}

\section{Research Article}

Keywords: Heavy metals, surface sediments, potential risk assessment, marine sediment, Gulf of Tokin, sediments

Posted Date: August 17th, 2021

DOI: https://doi.org/10.21203/rs.3.rs-713261/v1

License: (9) This work is licensed under a Creative Commons Attribution 4.0 International License. Read Full License

Version of Record: A version of this preprint was published at Environmental Science and Pollution Research on January 28th, 2022. See the published version at https://doi.org/10.1007/s11356-022-18881-0. 


\section{Abstract}

Heavy metals contamination in sediments may endanger ecosystems and human health via the food chain. In fact, there is little to no understanding about heavy metal accumulation in surface sediment of one of the most economically important marine bodies for Vietnam, the Thai Binh Coast, where five large rivers co-discharge into the Gulf of Tonkin. Twenty-seven surface sediment samples were collected from the intertidal regions and analyzed for: arsenic (As), cadmium (Cd), chromium ( $\mathrm{Cr})$, copper $(\mathrm{Cu})$, mercury $(\mathrm{Hg})$, nickel $(\mathrm{Ni})$, and zinc $(\mathrm{Zn})$ using inductively coupled plasma mass spectroscopy (ICP-MS). The studied area exhibited a large spatial variation in the concentration of heavy metals, e.g., the dry sediment concentration of $\mathrm{Cd}$ was the least (0.05-0.49 mg. $\left.\mathrm{kg}^{-1}\right)$, whereas that of $\mathrm{Zn}$ was the greatest (45.4-252 mg. $\left.\mathrm{kg}^{-1}\right)$. Based on the geoaccumulation index $\left(I_{g e o}\right)$, most of the studied heavy metals were accumulated at low pollution levels, except four locations exhibited moderately and highly polluted levels of $\mathrm{Hg}$ with $I_{g e o} \mathrm{Hg}$ values from 1.92 to 2.66. Whereas the high contamination factor value implicated that not only $\mathrm{Hg}$ but also all other detected heavy metals in this area resulted from anthropogenic activities along the coast and the river upstream. This implied the need for quick action from the government.

\section{Introduction}

Thai Binh is a deltaic coastal province in the southern part of the Red River delta, with three sides facing the river and one side facing the Gulf of Tonkin at $20^{\circ} 17^{\prime}-20^{\circ} 44^{\prime}$ north latitude and $106^{\circ} 06^{\prime}-106^{\circ} 39^{\prime}$ east longitude. Along the 59-km coastline, five rivers flow into the Gulf, namely: Tra Ly, Lan, Ba Lat [Hong], Thai Binh, and Diem Ho, creating a large intertidal area of approximately 25,000 ha where saltwater from the Gulf intersects with river discharge, creating a bountiful ecosystem that is favorable for the development of aquaculture (e.g., clam, shrimp) and thus, is an economically important marine ecosystem ( $\mathrm{Ngo}$ et al. 2018). Consequently, the intertidal region of the Thai Binh coast is exemplified the transition zone from ocean to land, where the flux of matter and energy is rapid, which has made it a site of international importance for wetland conservation (Hai et al. 2015). Therefore, information about the Thai Binh coast provides references for similar environments in other parts of the world, especially where similar aquaculture techniques may be used or under consideration.

Rapid industrialization and urbanization inland and on the coast can render the intertidal zone more vulnerable to many kinds of metallic and organic pollutants (Hu et al. 2013; Gaonkar et al. 2021; Merhabi 2021). Among them, heavy metals are reported as the most hazardous in the aquatic environment and may pose a serious threat to human health, with arsenic (As), cadmium (Cd), and mercury ( $\mathrm{Hg}$ ) at the top of the hazards list (ATSDR 2019). These three metals can be released by anthropogenic activities or leached from soils, and transported by aquatic systems to the intertidal coast, and deposited on the surface sediment (Amankwaa et al. 2021). As a result, sediments can act as sources of heavy metals (El Nemr et al. 2016; Nour 2019; Shilla et al. 2019; Ye et al. 2020). It is believed that heavy metals can leach from surface sediments to enter food webs and then be biomagnified (Hosono et al. 2011; El Nemr et al. 2016; Ranjbar Jafarabadi et al. 2018; Amankwaa et al. 2021). Thus, the surface sediment quality of the intertidal coast is an essential indicator of environmental pollution (Yang et al. 2012; Zhu et al. 2012) and the potential risk to human health of aquatic produce from these areas (El Nemr et al. 2016).

This study assesses the accumulation of arsenic (As), cadmium (Cd), chromium (Cr), copper (Cu), mercury (Hg), nickel (Ni), and zinc $(\mathrm{Zn})$ in the surface intertidal sediments at some estuaries of the Thai Binh coast, the Gulf of Tonkin, Vietnam. Two indices were used to assess the current state of pollution, and investigate the source of these metals, and examine the potential ecological risk.

\section{Materials And Methods}

Study areas 
Every year, the Hong-Thai Binh river system discharges $\sim 120 \times 10^{9} \mathrm{~m}^{3}$ of water and deposits $114 \times 10^{6}$ tons of silt in coastal areas. The annual flow of water is mainly concentrated in the rainy season $\left(300 \mathrm{~m}^{3} . \mathrm{s}^{-1}\right.$ and $2200 \mathrm{~m}^{3} . \mathrm{s}^{-1}$, from June to September), and just $50-300 \mathrm{~m}^{3} . \mathrm{s}^{-1}$ during the remaining months are typically low (Table S4) (Vietnam Government Portal, 2010).

The coastal estuaries of the Thai Binh Province have a relatively uniform tidal regime, with the diurnal tide gradually decreasing from the north to the south. The maximum amplitude of tides ranges from 3.5 to $4.0 \mathrm{~m}$, with an average of 1.7$1.9 \mathrm{~m}$ and a minimum of $0.3-0.5 \mathrm{~m}$. The highest tide in a year can reach $4.0 \mathrm{~m}$, and the lowest tide can be $0.08 \mathrm{~m}$. Because of the high tide amplitude, salinity ranges from $5 \%$ o to $20 \%$, and tides can result in considerably deep penetration of river mouths: $14 \mathrm{~km}$ for the Red River and $20 \mathrm{~km}$ for Tra Ly River. As shown in Table S4, the flow of rivers is lower in April than in the rainy season. During this time, the low water level facilitates seawater penetration into the land, especially saline intrusion.

Coastal flow in Thai Binh is a combination of tides, wind, waves, river flow, and the characteristics of the Gulf of Tonkin. Flows in estuarine areas are often strongly influenced by the river, whereas flow is predominantly caused by wind in the outermost sea surface. In the northeast wind field, the longshore surface current flow, influenced by the north wind, varies in a direction depending on the intensity of the river flow and the coastal terrain. The south wind is prevalent in the southeast wind field, and the surface flows along with the shore. The tidal flow and tidal composition play a decisive role in the integrated flow in the coastal area of Thai Binh.

\section{Sampling}

Sediment samples for the study were collected from 27 intertidal sites in northeast Vietnam during the dry season (i.e., April 1-10). Samples were collected from the estuaries of the Thai Binh, Diem Ho, Tra Ly, Lan, and Hong River mouths (Ba Lat estuary) and adjacent sites (Fig. 1). For each cross-section, three sampling sites, namely low, middle, and high tide marks, were obtained from inland. Specific sampling locations are shown in Fig. 1. All sediment samples were collected and carefully preserved to avoid contamination of samples. At each sampling site, five large samples were collected from a square area (each edge 20-m long), one sample from each corner, and the fifth from the intersection of the two diagonals. Each large sample consisted of three smaller samples that were collected 5-m apart. Samples were taken from a depth of $0-10 \mathrm{~cm}$ and stored in polyethylene bags at $4^{\circ} \mathrm{C}$ until later analysis. A handheld GPS device was used to fix the sampling location. All steps were accorded to the National Technical Regulation on the use of certified reference materials (CRM) in the analysis of geology and minerals (QCVN43:2012/BTNMT 2017).

Analytical procedures

The grain-size distribution of sediments was calculated by wet sieving of sand and gravel and by using the pipetting technique for silt and clay fractions (Robert L. 1980). Sediment samples were placed with weighting paper and dried out at $60^{\circ} \mathrm{C}$ in the oven until the weight was unchanged. Then, the dried sediments were milled to have a size $<2 \mathrm{~mm}$ before further measurement. Total organic carbon (TOC) of samples was calculated following the ISO 14235:1998, which is by reaction of samples with excess $\mathrm{K}_{2} \mathrm{Cr}_{2} \mathrm{O}_{7}-\mathrm{H}_{2} \mathrm{SO}_{4}$ solution and the excess being titrated using Mohr's salt $\left[\left(\mathrm{NH}_{4}\right)_{2} \mathrm{Fe}\left(\mathrm{SO}_{4}\right)_{2}\right] \cdot 6 \mathrm{H}_{2} \mathrm{O}(\mathrm{ISO}$ 1998). Heavy metals were extracted from accurately weighed $0.25 \mathrm{~g}$ sample in polyfluorocarbon tubes by wetting with $2 \mathrm{~mL}$ of $\mathrm{HNO}_{3}, 6 \mathrm{~mL}$ of concentrated $\mathrm{HCl}$, and $2 \mathrm{~mL}$ of $\mathrm{HF}$ (El-Sorogy et al. 2016) and allowing to stand at room temperature overnight. The next day, samples were digested under pressure using a microwave system, increasing the temperature to $180^{\circ} \mathrm{C}$ in 15 minutes and maintaining that temperature for $30 \mathrm{~min}$ (QCVN43:2012/BTNMT 2017). Solutions were allowed to cool to room temperature, then transferred to plastic volumetric cylinders and diluted to $50 \mathrm{~mL}$ with deionized water. According to the manufacturer's recommendations, the concentrations of $\mathrm{As}, \mathrm{Cd}, \mathrm{Cr}, \mathrm{Cu}, \mathrm{Hg}, \mathrm{Ni}$, and $\mathrm{Zn}$ were determined by inductive coupled plasma mass spectrometry (ICP-MS, model 7900 Agilent, USA). All digests were repeated at least twice, i.e., the values are means of at least three independent measurements. The standard deviation of independent replicate analyses was less than $\pm 10 \%$. The ICP-MS was calibrated using purchased solutions of certified concentration. Accuracy 
was assessed using the European Commission's standard reference material BCR-277R, and the recovery of spikes of As, $\mathrm{Cd}, \mathrm{Cr}, \mathrm{Cu}, \mathrm{Hg}, \mathrm{Ni}$, and $\mathrm{Zn}$, and of elements in BCR-277R ranged from 90-110\%. In all the analyses blanks were performed and modifications were given if required. All the measurements were taken in triplicate and average results are provided.

Pollution assessment criteria

This study used the standards on sediment quality established by Ontario Canada's Ministry of the Environment (OCME 2008) and the Environment Protection Agency (EPA), USA (Long et al. 1995). The ratings for these parameters are shown in Table 1.

Table 1

Standards for assessment of metal pollution in sediments

\begin{tabular}{|c|c|c|c|c|c|}
\hline \multirow[t]{2}{*}{ Elements } & \multicolumn{2}{|c|}{$\begin{array}{l}\text { Guidelines of EPA USA } \\
\text { (mg.kg }{ }^{-1}, \text { dry weight) }\end{array}$} & \multicolumn{3}{|c|}{$\begin{array}{l}\text { Ontario Canada's Ministry of the Environment } \\
\text { (mg.kg-1, dry weight) }\end{array}$} \\
\hline & ERL & ERM & No effect & lowest effect & Severe effect \\
\hline As & 8.20 & 70.0 & N. A & 6.00 & 33.0 \\
\hline $\mathrm{Cd}$ & 1.20 & 9.60 & N. A & 0.60 & 10.0 \\
\hline $\mathrm{Cr}$ & 81.0 & 370 & N. A & 26.0 & 110 \\
\hline $\mathrm{Cu}$ & 34.0 & 270 & N. A & 16.0 & 110 \\
\hline $\mathrm{Hg}$ & 0.15 & 0.71 & N. A & 0.20 & 2.00 \\
\hline $\mathrm{Ni}$ & 20.9 & 51.6 & N. A & 16.0 & 75.0 \\
\hline $\mathrm{Zn}$ & 150 & 410 & N. A & 120 & 820 \\
\hline
\end{tabular}

Assessment of heavy metal contamination in sediment by using indicators.

The $I_{g e o}$, potential ecological risk of a single element $\left(E r^{\prime}\right)$, and potential toxicity response index for various heavy metals in the sediments (RI) were used to assess the cumulative origin of heavy metals in the intertidal sediments.

The geoaccumulation index $\left(I_{\text {geo }}\right)$

$I_{g e o}$ is a quantitative measurement of the level of contamination in sediments and freshwater environments. $I_{\text {geo }}$ is calculated by comparing the total metal content in a sample with the base value of the metal (in this study, heavy metal content in the earth's crust was used as the base value); thus, an increase in the present level is predicted to be due to human activity affecting the natural environment. This index is calculated after Muller (1969), and after that, it has been successfully applied by many researchers (Muller 1969; El-Sorogy et al. 2016; Beata et al. 2018; Dash et al. 2021). The index was calculated as Eq. (1):

$I_{\text {geo }}=\log _{2}\left(\frac{C_{n}}{1.5 \times B_{n}}\right)$

Where $C_{n}$ is the total measured concentration of the metal $n$, and $B_{n}$ is the geochemical background of the metal $n$ obtained from Turekian Karl's measurements (Turekian et al. 1961). Factor 1.5 is a background matrix correction factor proposed to minimize the impact of possible changes on the baseline because of lithological changes in sedimentary rocks. According to (Loska et al. 1997), the classification of the sediment pollution level is as follows: $I_{\text {geo }} \leq 0$ (unpolluted); $0<I_{\text {geo }}<1$ (unpolluted to moderately polluted); $1<I_{\text {geo }}<2$ (moderately polluted); $2<I_{\text {geo }}<3$ (moderately to strongly polluted); $3<I_{\text {geo }}<$ 4 (strongly polluted); $4<I_{\text {geo }}<5$ (strongly to extremely polluted); and $5<I_{\text {geo }}$ (extremely polluted). 
$\mathrm{CF}$ is used to evaluate the contamination of heavy metals in sediments and is calculated by the ratio of the concentration of each metal in sediment to its base value. The formula (2) is as follows (Hakanson 1980):

$\mathrm{CF}_{i}=\frac{C_{m}^{i}}{C_{B}}$

$C_{m}^{i}$ is the heavy metal content of the studied sediment, whereas $C_{B}$ is the heavy metal content in the substrate, after accounting for the average content in the shale (Turekian et al. 1961). Pollutants are classified into four levels (Liu et al., 2005): $\mathrm{CF}<1$ (low CF ); $1 \leq \mathrm{CF}<3$ (moderate CF); $3 \leq \mathrm{CF}<6$ (considerable CF); and $6 \leq \mathrm{CF}$ (very high $\mathrm{CF}$ ).

$E r^{i}$ is the potential ecological risk factor of single metal $i$. The calculation of $E r^{i}$ is deduced as follows:

$E r^{i}=\operatorname{Tr}^{i} \times C F^{i}(3)$

where $T r^{i}$ is the response coefficient for the toxicity of the $\mathrm{i}_{\text {th }}$ heavy metal. The corresponding $\operatorname{Tr}^{i}$ listed values are as follows: $\mathrm{Hg}=40, \mathrm{Cd}=30, \mathrm{As}=10, \mathrm{Cu}=\mathrm{Ni}=5, \mathrm{Cr}=2$, and $\mathrm{Zn}=1$ (El Nemr et al. 2016); $C F^{i}$ is the contamination factor which calculated in Eq. (2). The levels of impact of the element on the sediment environment were as follows: $\mathrm{Er}^{i}<40$ (low potential ecological risk), $40 \leq E r^{i}<80$ (moderate potential ecological risk), $80 \leq E r^{i}<160$ (considerable potential ecological risk), $160 \leq E r^{i}<320$ (high potential ecological risk), and $E r^{i} \geq 320$ (serious ecological risk).

Finally, RI was obtained using Eq. (4).

$\mathrm{RI}=\sum E r^{i}=\sum T r^{i} \times C F^{i}$

The impact of potential ecological risk factors on the study elements was classified into four levels: RI < 150 (potentially low ecological risk), $150 \leq \mathrm{RI}<300$ (moderately potential ecological risks), $300 \leq \mathrm{RI}<600$ (considerably potential ecological risk), and $600 \leq \mathrm{RI}$ (seriously potential ecological risk) (Guo et al. 2010).

\section{Statistical analysis}

Multivariate statistical techniques, including Pearson Correlation Matrix (PCM) and Principal Component Analysis (PCA), were performed using OriginPro 2021 learning edition (OriginLab Corporation, Northampton, MA, USA) software packages. PCA is a strong pattern recognition approach that seeks to explain the variation of a large set of inter-correlated variables (Ranjbar Jafarabadi et al. 2018). It denotes the connection of variables, therefore decreasing the dimensionality of the data collection. PCA was conducted on the raw data set of heavy metals, TOC content, and grain components of the sediments in this work. The loading from PCA analysis provides information on the correlation between variables. Besides, their contribution to modeling and their effect on sample cluster separation also can be obtained. We are grateful to Originlab for providing a free student edition.

\section{Results}

3.1 Heavy metals and TOC distribution in sediment

The results of some heavy metals and TOC content in sediments on the Thai Binh coast are summarized in Table 2. Besides, the spatial variations of seven metals were represented in Table S1, Figure S1. 
Table 2

Concentration of some heavy metals and TOC in sediment

\section{Concentration ( $\left.\mathrm{mg}^{\mathrm{kg}}{ }^{-1}\right)$}

\begin{tabular}{llllllll}
\hline As & $\mathrm{Cd}$ & $\mathrm{Cu}$ & $\mathrm{Cr}$ & $\mathrm{Hg}$ & $\mathrm{Ni}$ & $\mathrm{Zn}$ & $\mathrm{TOC}$
\end{tabular}

\begin{tabular}{|c|c|c|c|c|c|c|c|c|}
\hline Average value & 15.36 & 0.26 & 41.39 & 39.59 & 0.98 & 27.39 & 93.11 & 1.14 \\
\hline Content range & $\begin{array}{l}7.00- \\
26.3\end{array}$ & $\begin{array}{l}0.049- \\
0.49\end{array}$ & $\begin{array}{l}8.65- \\
71.9\end{array}$ & $\begin{array}{l}24.6- \\
62.3\end{array}$ & $\begin{array}{l}0.12- \\
3.79\end{array}$ & $\begin{array}{l}11.2- \\
43.7\end{array}$ & $\begin{array}{l}45.4- \\
252\end{array}$ & $\begin{array}{l}0.13- \\
5.47\end{array}$ \\
\hline Standard deviation & 5.33 & 0.12 & 19.32 & 9.72 & 0.85 & 6.91 & 44.28 & 1.10 \\
\hline CV (\%) & 28.4 & 0.01 & 373 & 94.5 & 0.72 & 47.8 & 1961 & 1.22 \\
\hline $\begin{array}{l}\text { aPercentage of national standard } \\
\text { limit exceed (\%) }\end{array}$ & 0 & 0 & 0 & 0 & 100 & - & 0 & - \\
\hline $\begin{array}{l}{ }^{b} \text { Percentage of ERL limit exceeded } \\
(\%)\end{array}$ & 100 & 0 & 100 & 0 & 100 & 100 & 0 & - \\
\hline 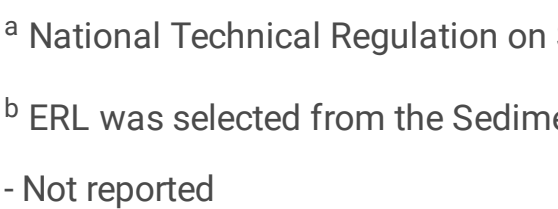 & $\begin{array}{l}\text { liment Q } \\
\text { Quality }\end{array}$ & $\begin{array}{l}\text { ality, } 2017 \\
\text { didelines c }\end{array}$ & US EPA & Table 1. & & & & \\
\hline
\end{tabular}

The spatial distribution of the seven heavy metals in sediments is shown in Figure S1 and Table S1. According to the ATSDR (ATSDR 2019), we divided the metals into two groups associated with their toxicity, including group I is with lower toxicity (i.e., $\mathrm{Cu}, \mathrm{Cr}, \mathrm{Ni}$, and $\mathrm{Zn}$ ) and group II is with higher toxicity (i.e., As, Cd, and $\mathrm{Hg}$ ).

The concentrations of the group I element were varied 8.65-71.9; $24.6-62.3 ; 11.2-43.7$; and 45.4-252 $\mathrm{mg}^{\mathrm{kg}}{ }^{-1} \mathrm{for} \mathrm{Cu}, \mathrm{Cr}$, $\mathrm{Ni}$, and $\mathrm{Zn}$, respectively (Table 2). The concentration of metals in decreasing order from the highest to lowest was as follows: $\mathrm{Zn}>\mathrm{Cu}>\mathrm{Cr}>\mathrm{Ni}$; this finding is in agreement with that of previous studies (Phuong et al. 2010; Tue et al. 2012; Ho et al. 2013). By comparing the concentrations of $\mathrm{Zn}, \mathrm{Cu}, \mathrm{Cr}$, and Ni with the OCME guidelines (Table 1), we found that three locations (TT24, TT14, and TT4) had the lowest level of Zn pollution. However, only TT24 and TT24 ranged between effects range low (ERL)-effects range medium (ERM) according to the US EPA 1998. Most of the locations were polluted by the three remaining metals at the lowest level with the exception of TT8 for Ni, TT21 for Ni, and TT8, TT21, and TT23 for Cu. Following the criteria by both the OCME and EPA (Table 1), no probable or severe effect could be detected. As also indicated in Table 2, the group I element was still in the range of the national standard limit. However, Ni and Cu were already passed the threshold of ERL value according to US EPA.

Regarding group II, we found that they were present at a considerably toxic level with some noticeable points. The concentration of $\mathrm{Cd}$ in the studied areas was lower than the lowest effect level according to the OCME, and the effect of this metal was rarely observed according to the EPA USA 1998 criterion (Table 1). On the other hand, As and Hg contamination in these areas varied. The mean of the As and $\mathrm{Hg}$ concentration, respectively, were $15.36 \mathrm{mg} . \mathrm{kg}^{-1}$ and $0.98 \mathrm{mg} . \mathrm{kg}^{-1}$ (Table 2). Such high concentrations have been seemingly predicted on the basis of statistics on the concentrations of metals in surface waters or in sediments from inland areas (Asian Development Bank 2007). In more detail, the highest concentration of As was $26.3 \mathrm{mg} \cdot \mathrm{kg}^{-1}$ at the sampling station TT4, and this concentration had not yet reached the level of severe impact. All samples were affected by As at the lowest level, and the concentration of As was between the ERL-ERM values. The concentration of $\mathrm{Hg}$ in sediments at some stations was particularly high. For example, the $\mathrm{Hg}$ concentration at the TT9 was $3.79 \mathrm{mg} \cdot \mathrm{kg}^{-1}$ of dry sediment; stations 12 and 22 (TT12 and TT22) had the same concentration of $2.28 \mathrm{mg} \cdot \mathrm{kg}^{-1}$ of dry 
sediment (Table S1). Those stations including (TT8, TT9, TT12, TT22) with Hg concentrations larger than $2.00 \mathrm{mg}^{\mathrm{kg}} \mathrm{kg}^{-1}$ indicated that they had reached a level of severity according to the Ontario provincial sediment quality guidelines, and frequent effects could be observed (Table 1 and Table S1).

Table 3 shows comparisons of heavy metal concentrations in the Thai Binh coast area with those in other referenced locations. The results showed that the concentrations range of $\mathrm{As}, \mathrm{Cd}, \mathrm{Cu}, \mathrm{Cr}, \mathrm{Hg}, \mathrm{Ni}$, and $\mathrm{Zn}$ in the research area were comparable to those found in the other locations indicated. The average metal concentrations in the research region, on the other hand, were significantly higher than those on the coast of the Mekong River. The major cause of the difference in concentration was the obvious anthropogenic activities (Liang et al. 2019; Dang Hoai et al. 2020). Compared to Duyen Hai Seaport, $\mathrm{Hg}$ concentration in this research seem significantly high, which can be explained only by human influence.

Table 3

Comparison of heavy metal in surface sediment in the Thai Binh coast area and representative seas (unit: $\mathrm{mg} . \mathrm{kg}^{-1}$ ).

\begin{tabular}{|c|c|c|c|c|c|c|c|c|}
\hline Location & As & Cd & $\mathrm{Cu}$ & $\mathrm{Cr}$ & $\mathrm{Hg}$ & $\mathrm{Ni}$ & Zn & Reference \\
\hline ThaiBinh coastal area & $\begin{array}{l}7.00- \\
26.3\end{array}$ & $\begin{array}{l}0.05- \\
0.49\end{array}$ & $\begin{array}{l}8.65- \\
71.9\end{array}$ & $\begin{array}{l}24.6- \\
62.3\end{array}$ & $\begin{array}{l}0.12- \\
3.79\end{array}$ & $\begin{array}{l}11.2- \\
43.7\end{array}$ & $\begin{array}{l}45.4- \\
252\end{array}$ & This study \\
\hline $\begin{array}{l}\text { Cam River Mouth, Haiphong } \\
\text { Province }\end{array}$ & $17-68$ & - & $\begin{array}{l}38- \\
123\end{array}$ & $\begin{array}{l}56- \\
110\end{array}$ & - & $\begin{array}{l}31- \\
48\end{array}$ & $\begin{array}{l}107- \\
272\end{array}$ & $\begin{array}{l}\text { (Ho et al. } \\
2013)\end{array}$ \\
\hline Duyen Hai Seaport Area & $\begin{array}{l}16.5- \\
22.8\end{array}$ & $\begin{array}{l}0.9- \\
9.15\end{array}$ & $\begin{array}{l}3.07- \\
9.15\end{array}$ & - & $\begin{array}{l}0.03- \\
0.31\end{array}$ & - & $\begin{array}{l}82.9- \\
212\end{array}$ & $\begin{array}{l}\text { (Tham et al. } \\
\text { 2021) }\end{array}$ \\
\hline $\begin{array}{l}\text { Mangrove Sediments from } \\
\text { the Ba Lat Estuary }\end{array}$ & - & $\begin{array}{l}0.20- \\
0.75\end{array}$ & $\begin{array}{l}60.04- \\
93.59\end{array}$ & $\begin{array}{l}64.94- \\
78.73\end{array}$ & - & - & $\begin{array}{l}76.53- \\
199.44\end{array}$ & $\begin{array}{l}\text { (Tue et al. } \\
\text { 2012) }\end{array}$ \\
\hline Mekong River Estuary ${ }^{a}$ & - & $\begin{array}{l}0.04- \\
0.10\end{array}$ & - & - & - & $\begin{array}{l}0.87- \\
8.30\end{array}$ & $\begin{array}{l}4.5- \\
99.0\end{array}$ & $\begin{array}{l}\text { (Nguyen et al. } \\
2020 \text { ) }\end{array}$ \\
\hline Ha Long Bay & $\begin{array}{l}1.78- \\
13.71\end{array}$ & $\begin{array}{l}0.03- \\
0.20\end{array}$ & $\begin{array}{l}3.80- \\
41.72\end{array}$ & - & - & - & $\begin{array}{l}6.34- \\
119.79\end{array}$ & $\begin{array}{l}\text { (Dang Hoai et } \\
\text { al. 2020) }\end{array}$ \\
\hline \multicolumn{9}{|c|}{ a only average value was reported } \\
\hline
\end{tabular}

3.2. Assessment of heavy metal contamination in sediment by using indicators

\subsubsection{Geoaccumulation $\left(I_{g e o}\right)$}

Figure 2 presents the calculated $I_{\text {geo }}$ values for $\mathrm{As}, \mathrm{Cd}, \mathrm{Cu}, \mathrm{Cr}, \mathrm{Ni}, \mathrm{Zn}$, and $\mathrm{Hg}$ in the studied area. The mean $I_{\text {geo }}$ values of the sediments of the intertidal surface of the coastal area of Thai Binh province with the elements $\mathrm{As}, \mathrm{Cd}, \mathrm{Cu}, \mathrm{Cr}, \mathrm{Hg}, \mathrm{Ni}, \mathrm{and} \mathrm{Zn}$ were $-0.43,-0.99,-0.90,-1.80,0.21,-1.94$, and -0.73 , respectively (Table S2). Based on these values, the cumulative level of heavy metal was as follows: $\mathrm{Hg}>\mathrm{As}>\mathrm{Zn}>\mathrm{Cu}>\mathrm{Cd}>\mathrm{Cr}>\mathrm{Ni}$. Comparing with the standards defined earlier, we concluded that most of the heavy metals at studied stations, which present the intertidal surface sediment, were not contaminants according to the previously defined criteria. Except for TT2, TT8, TT11, TT12, TT22, TT26, they were moderately polluted, and TT9 was from moderately to strongly polluted. The explanation for this phenomenon could be from the clam and shrimp culture of people in the studied area. It was reported that before every new growing season, growing ponds were rinsed with chemicals to kill fungi and viruses such as Falizan, Sinment (GAE 2016). Unfortunately, such fungicides contain some amount of $\mathrm{Hg}$. Other researchers reported that some pollutants originated from industrial waste, sewage runoff, and agricultural discharge accumulated in sediment could be released and affected the marine ecosystem (He et al. 2021; Tham et al. 2021). Therefore, there is a need for a better policy and more examination from the government. 


\subsubsection{Contamination factor}

The CF indicated the metal pollution of sediments at different levels (Fig. 3). The highest value of $\mathrm{CF}_{\mathrm{Hg}}$ of approximately 9.47 was at station 9 (Table S3), which indicated that $\mathrm{Hg}$ was a very high CF at this station. No other report concurs with this unexpected value. Therefore, careful evaluation is required to assess this factor in the studied area. Moreover, stations $4,11,14,16,22,24-26$ were moderately contaminated by As and Zn, according to CF. The effect trend of $I_{\text {geo }}$ was repeated, and the $\mathrm{CF}$ of the studied heavy metal decreased as follows: $\mathrm{Hg}>\mathrm{As}>\mathrm{Zn}>\mathrm{Cu}>\mathrm{Cd}>\mathrm{Cr}>\mathrm{Ni}$. There were differences in the CF value between heavy metals because of feature activities along the river basin. However, these generally high $\mathrm{CF}$ values at all the studied locations implicated that not only $\mathrm{Hg}$ as discussed above was polluted by human activities, but also the other heavy metal. This intertidal ecosystem may be critically affected by anthropogenic contamination such as mining from upstream.

\subsection{3. $E r^{i}$ and RI}

As shown in Fig. 4 and Table S5, the $\mathrm{Er}^{\mathrm{r}}$ and RI values of most of the sediment samples in the research area were lower than 40 and 150, respectively. This reflects that the Thai Binh coastal region generally poses a low potential ecological risk for most of the detected metals. However, a few stations pose a high risk. TT2, TT3, TT8-TT12, TT15, TT17, TT22, TT25, and TT26 had higher than the moderate ecological risk for $\mathrm{Hg}$, and the same condition was observed in TT11 for Cd. TT8, TT9, TT12, and TT22 stations had reached a severely potential risk position for $\mathrm{Hg}$. The concentration of $\mathrm{Hg}$ in this region showed a similar trend but with higher values than those reported by (Wang et al. 2013; Zhuang and Gao 2015; El Nemr et al. 2016). Regular monitoring and assessment should be conducted at the sampling locations where As and $\mathrm{Hg}$ pose moderate and considerable levels of risk.

\section{Discussion}

Table 4 shows the Pearson's correlation coefficients $(P)$ of seven heavy metals, TOC, and grain size proportion in sediments with statistical significance at $p<0.05$. Individual heavy metal correlations are mainly positive, with several nearing 1.0 (e.g., $\mathrm{P}_{\mathrm{Ni}-\mathrm{Cr}}=0.89, \mathrm{P}_{\mathrm{Cd}-\mathrm{As}}=0.72, \mathrm{P}_{\mathrm{Ni}-\mathrm{Cu}}=0.76$, and $\mathrm{P}_{\mathrm{Cu}-\mathrm{Cr}}=0.72$ ). The amount of heavy metal contamination can be revealed by a substantial positive association between metal (i.e., As, Cd, Cu, Zn, Ni) and total organic carbon (TOC). Hg exhibited the lowest relationship with total organic carbon $\left(\mathrm{P}_{\mathrm{Hg}-\mathrm{TOC}}<0\right)$. There were significant variations in the Pearson correlation values between individual metals such as $\mathrm{Cu}, \mathrm{Pb}, \mathrm{Zn}, \mathrm{Cd}$, and $\mathrm{Cr}$ along the Saigon-Dong Nai River estuary. TOC has a strong correlation with clay and silt. The small size of clay and silt may carry TOC better than large size (i.e., sand).

The particle size decreased with an increase in the distance of the sampling location from the estuary because large particles were difficult to be flown far away. All stations contained sand (40.295.3\%), and small-sized particles were present in relatively small proportions; however, the higher their concentration, the higher the TOC concentration (Tyson 1995). TOC is a critical indicator for assessing pollution levels (Tham et al. 2021). The TOC concentration in some stations was low (< $1.0 \%$ of dry sediment Table S1, suggesting that TOC was mainly of marine origin (Youssef and El-Said 2011). On the contrary, TT4 was reported with a TOC concentration of $5.47 \%$, which highly suggested it may come from the continent.

Generally, at the sampling sites near major estuaries (TT1-TT3, TT7, TT13, TT25), surface sediments had a relatively high concentration of heavy metals. This may be attributed to the interaction of the sea with a high amount of matter from the continent (Youssef and El-Said 2011; Wang et al. 2013). However, considering that only reason, we cannot explain for the TT4 or the TT22 where many heavy metals have the highest concentration among this study. One possible explanation is the flow rate of the river. Table S4 showed that Ba Lat or Hong estuary has a considerably high flow rate. As a result, water can flow further, and then, the tidal brings it back to be more settled on both sides of the estuary. The other explanation is from human activities such as aquacultural. Therefore, a synergy of many processes should be considered to provide a 
better understanding (Bryan and Langston 1992). Besides, other indices (e.g., I geo are also important because considering a single metal does not describe the real potential risk of the studied area. 
Pearson Correlations of some heavy metals, TOC, and grain size in sediments of Thai Binh, Vietnam

\begin{tabular}{|c|c|c|c|c|c|c|c|c|c|c|c|c|}
\hline & & As & $\mathrm{Cd}$ & $\mathrm{Cu}$ & $\mathrm{Cr}$ & $\mathrm{Hg}$ & $\mathrm{Ni}$ & $\mathrm{Zn}$ & TOC & Clay & Silt & Sand \\
\hline \multirow[t]{2}{*}{ "As" } & $\begin{array}{l}\text { Pearson } \\
\text { Corr. }\end{array}$ & 1.00 & & & & & & & & & & \\
\hline & p-value & - & & & & & & & & & & \\
\hline \multirow[t]{2}{*}{ "Cd" } & $\begin{array}{l}\text { Pearson } \\
\text { Corr. }\end{array}$ & 0.72 & 1.00 & & & & & & & & & \\
\hline & p-value & $\begin{array}{l}2.23 \mathrm{E}- \\
5\end{array}$ & - & & & & & & & & & \\
\hline \multirow[t]{2}{*}{ "Cu" } & $\begin{array}{l}\text { Pearson } \\
\text { Corr. }\end{array}$ & 0.38 & 0.61 & 1.00 & & & & & & & & \\
\hline & p-value & 0.05 & $\begin{array}{l}7.78 \mathrm{E}- \\
4\end{array}$ & - & & & & & & & & \\
\hline \multirow[t]{2}{*}{ "Cr" } & $\begin{array}{l}\text { Pearson } \\
\text { Corr. }\end{array}$ & 0.69 & 0.69 & 0.72 & 1.00 & & & & & & & \\
\hline & $\mathrm{p}$-value & $\begin{array}{l}7.43 \mathrm{E}- \\
5\end{array}$ & $\begin{array}{l}6.35 \mathrm{E}- \\
5\end{array}$ & $\begin{array}{l}2.42 \mathrm{E}- \\
5\end{array}$ & - & & & & & & & \\
\hline \multirow[t]{2}{*}{ "Hg" } & $\begin{array}{l}\text { Pearson } \\
\text { Corr. }\end{array}$ & -0.29 & 0.05 & 0.32 & -0.11 & 1.00 & & & & & & \\
\hline & $\mathrm{p}$-value & 0.14 & 0.82 & 0.11 & 0.57 & - & & & & & & \\
\hline \multirow[t]{2}{*}{ "Ni" } & $\begin{array}{l}\text { Pearson } \\
\text { Corr. }\end{array}$ & 0.60 & 0.65 & 0.76 & 0.89 & 0.07 & 1.00 & & & & & \\
\hline & p-value & $\begin{array}{l}8.69 \mathrm{E}- \\
4\end{array}$ & $\begin{array}{l}2.78 \mathrm{E}- \\
4\end{array}$ & $\begin{array}{l}4.70 \mathrm{E}- \\
6\end{array}$ & $\begin{array}{l}4.23 \mathrm{E}- \\
10\end{array}$ & 0.73 & - & & & & & \\
\hline \multirow[t]{2}{*}{ "Zn" } & $\begin{array}{l}\text { Pearson } \\
\text { Corr. }\end{array}$ & 0.55 & 0.51 & 0.37 & 0.51 & -0.20 & 0.42 & 1.00 & & & & \\
\hline & $\mathrm{p}$-value & 0.003 & 0.006 & 0.06 & 0.007 & 0.33 & 0.03 & - & & & & \\
\hline \multirow[t]{2}{*}{ "TOC" } & $\begin{array}{l}\text { Pearson } \\
\text { Corr. }\end{array}$ & 0.49 & 0.51 & 0.37 & 0.69 & -0.06 & 0.62 & 0.40 & 1.00 & & & \\
\hline & $\mathrm{p}$-value & 0.009 & 0.006 & 0.06 & $\begin{array}{l}6.78 \mathrm{E}- \\
5\end{array}$ & 0.77 & $\begin{array}{l}4.99 \mathrm{E}- \\
4\end{array}$ & 0.04 & - & & & \\
\hline \multirow[t]{2}{*}{ "Clay" } & $\begin{array}{l}\text { Pearson } \\
\text { Corr. }\end{array}$ & 0.67 & 0.71 & 0.57 & 0.84 & 0.05 & 0.85 & 0.44 & 0.79 & 1.00 & & \\
\hline & p-value & $\begin{array}{l}1.24 \mathrm{E}- \\
4\end{array}$ & $\begin{array}{l}2.84 \mathrm{E}- \\
5\end{array}$ & 0.002 & $\begin{array}{l}5.49 \mathrm{E}- \\
8\end{array}$ & 0.82 & $\begin{array}{l}1.81 \mathrm{E}- \\
8\end{array}$ & 0.02 & $\begin{array}{l}1.05 \mathrm{E}- \\
6\end{array}$ & - & & \\
\hline \multirow[t]{2}{*}{ "Silt" } & $\begin{array}{l}\text { Pearson } \\
\text { Corr. }\end{array}$ & 0.74 & 0.75 & 0.55 & 0.87 & -0.08 & 0.86 & 0.45 & 0.75 & 0.94 & 1.00 & \\
\hline & $\mathrm{p}$-value & $\begin{array}{l}1.10 \mathrm{E}- \\
5\end{array}$ & $\begin{array}{l}6.21 \mathrm{E}- \\
6\end{array}$ & 0.003 & $\begin{array}{l}2.77 \mathrm{E}- \\
9\end{array}$ & 0.70 & $\begin{array}{l}1.24 \mathrm{E}- \\
8\end{array}$ & 0.02 & $\begin{array}{l}6.76 \mathrm{E}- \\
6\end{array}$ & $\begin{array}{l}8.3 \mathrm{E}- \\
13\end{array}$ & - & \\
\hline \multirow[t]{2}{*}{ "Sand" } & $\begin{array}{l}\text { Pearson } \\
\text { Corr. }\end{array}$ & -0.34 & -0.50 & -0.39 & -0.52 & 0.20 & -0.52 & -0.27 & -0.39 & -0.56 & -0.57 & 1.00 \\
\hline & $\mathrm{p}$-value & 0.08 & 0.01 & 0.05 & 0.006 & 0.32 & 0.005 & 0.17 & 0.05 & 0.003 & 0.002 & - \\
\hline
\end{tabular}


The top two PCA axes' eigenvalues accounted for $72.12 \%$ of the overall variance (Table S6). Except for sand and $\mathrm{Hg}$, all other parameters were positively linked with PC1 (Table S7), while $\mathrm{Cu}$ and $\mathrm{Hg}$ were positively associated with PC2 ( $r=0.42$ for $\mathrm{Cu}$ and $r=0.79$ for $\mathrm{Hg}$ ). From the PCA diagram, we can see that those locations in the positive direction of PC1 were likely to have a high concentration of $\mathrm{Cu}, \mathrm{Zn}, \mathrm{As}$, Ni while having very low sand content. The explanation can be from the hydrology condition; low hydrology ineffectively dilutes heavy metals. Besides, for those locations on the upper right of the diagram, particularly sample TT9 and TT12, they were highly polluted with Hg indicates the presence of Hg contamination source related to it. In fact, the ThaiBinh province has a relatively poor waste treatment system, including solid waste and wastewater. Furthermore, the overuse of pesticides and fungicides, as mentioned in Sect. 3.2.1, makes the pollution situation in this study area more severe.

\section{Conclusions}

The ecological risk of $\mathrm{As}, \mathrm{Cd}, \mathrm{Cu}, \mathrm{Cr}, \mathrm{Hg}, \mathrm{Ni}$, and $\mathrm{Zn}$ in 27 surface coastal sediment samples collected from the Thai Binh coast, the Gulf of Tonkin, Vietnam, in 2017 was evaluated using different analysis methods, namely $I_{\text {geo, }} \mathrm{CF}, \mathrm{Er}^{\prime}$, and RI. Zn was the dominant heavy metal in sediment samples. However, its concentration was presented as a low pollution risk. The concentration of the studied heavy metal was sequenced as $\mathrm{Zn}>\mathrm{Cu}>\mathrm{Cr}>\mathrm{Ni}>\mathrm{As}>\mathrm{Hg}>\mathrm{Cd}$. According to the $I_{g e o}$ value, except for $\mathrm{Hg}$, the levels of detected metals in Thai Binh coast were relatively low. CF indicates that most of the sediment deposition was drastically affected by anthropogenic activities. The $\mathrm{Er}^{\mathrm{i}}$ and RI indicate that heavy metals in sediments did not pose any ecological risk except for $\mathrm{Hg}$.

\section{Declarations}

\section{Ethical approval}

Not applicable

\section{Consent to participate}

Not applicable

\section{Consent to publish}

Not applicable

\section{Availability of data and materials}

All data generated or analyzed during this study are included in this published article [and its supplementary information files] and available from the corresponding author on reasonable request.

\section{Declaration of competing interest}

The authors declare that they have no known competing financial interests or personal relationships that could have appeared to influence the work reported in this paper.

\section{Funding}


This study was financially supported by the Vietnam Academy of Science and Technology supported grant number: VAST 06.03/20-21 and VAST.06.06/19-20.

\section{Authors' contributions}

Duong Thi Lim: Conceptualization, Methodology, Writing - original draft, Project administration. Nguyen Quang Bac: Formal analysis, Validation, Writing - review \& editing. Dao Dinh Cham: Investigation, Resources. Dao Ngoc Nhiem: Funding acquisition, Supervision. Nguyen Thi Lan Huong: Investigation, Resources. Nguyen Thi Huong Thuy: Data curation, Resources. Nguyen Thi Ha Chi: Data collection, analysis. Duong Cong Dien: Investigation, Resources, Visualization. Ngo Nghia Pham: Writing - review \& editing.

\section{Acknowledgements}

This study was financially supported by the Vietnam Academy of Science and Technology supported, grant number: VAST06.03/20-21 and VAST.06.06/19-20.

\section{References}

1. Amankwaa G, Yin X, Zhang L et al (2021) Spatial distribution and eco-environmental risk assessment of heavy metals in surface sediments from a crater lake (Bosomtwe/Bosumtwi). Environ Sci Pollut Res 28:19367-19380. https://doi.org/10.1007/s11356-020-12112-0

2. Asian Development Bank (2007) Viet Nam: Song Bung 4 Hydropower Project Phase II. https://www.adb.org/sites/default/files/project-document/74343/36352-vie-seia-0.pdf

3. ATSDR (2019) The ATSDR 2019 Substance Priority List. https://www.atsdr.cdc.gov/spl/index.html

4. Beata J, Ryszard K, Michał M, Zaleski G, s siorek T (2018) Pollution indices as useful tools for the comprehensive evaluation of the degree of soil contamination-A review. Environ Geochem Health 40:2395-2420. https://doi.org/10.1007/s10653-018-0106-z

5. Bryan GW, Langston WJ (1992) Bioavailability, accumulation and effects of heavy metals in sediments with special reference to United Kingdom estuaries: a review. Environ Pollut 76:89-131. https://doi.org/10.1016/02697491(92)90099-V

6. Dang Hoai N, Nguyen Manh H, Tran Duc T et al (2020) An assessment of heavy metal contamination in the surface sediments of Ha Long Bay, Vietnam. Environ Earth Sci 79:1-13. https://doi.org/10.1007/s12665-020-09192-z

7. Dash S, Borah SS, Kalamdhad AS (2021) Heavy metal pollution and potential ecological risk assessment for surficial sediments of Deepor Beel, India. Ecol Indic 122:107265. https://doi.org/10.1016/j.ecolind.2020.107265

8. El-Sorogy AS, Youssef M, Al-Kahtany K, Al-Otaiby N (2016) Assessment of arsenic in coastal sediments, seawaters and molluscs in the Tarut Island, Arabian Gulf, Saudi Arabia. J African Earth Sci 113:65-72.

https://doi.org/10.1016/j.jafrearsci.2015.10.001

9. El Nemr A, El-Said GF, Khaled A, Ragab S (2016) Distribution and ecological risk assessment of some heavy metals in coastal surface sediments along the Red Sea, Egypt. Int J Sediment Res 31:164-172. https://doi.org/10.1016/j.ijsrc.2014.10.001

10. GAE (2016) Project of buldong capacity for removal of POPs in Vietnam. http://www.gef.monre.gov.vn/wpcontent/uploads/2016/01/PO

11. Gaonkar CV, Nasnodkar MR, Matta VM (2021) Assessment of metal enrichment and contamination in surface sediment of Mandovi estuary, Goa, West coast of India. Environ Sci Pollut Res. https://doi.org/10.1007/s11356-021-14610-1 
12. Guo W, Liu X, Liu Z, Li G (2010) Pollution and potential ecological risk evaluation of heavy metals in the sediments around Dongjiang Harbor, Tianjin. Procedia Environ Sci 2:729-736. https://doi.org/10.1016/j.proenv.2010.10.084

13. Hai LT, Thinh NA, Tuan TA et al (2015) Impacts of climate change on agro-ecological landscapes in the coastal area of the thai binh province (Vietnam) using the delphi technique. Int J Clim Chang Strateg Manag 7:222-239.

https://doi.org/10.1108/IJCCSM-07-2013-0093

14. Hakanson L (1980) An ecological risk index for aquatic pollution control.a sedimentological approach. Water Res 14:975-1001. https://doi.org/10.1016/0043-1354(80)90143-8

15. He Y, Guo C, Lv J et al (2021) Occurrence, sources, and ecological risks of three classes of insecticides in sediments of the Liaohe River basin, China. https://doi.org/10.1007/s11356-021-15060-5

16. Ho HH, Swennen R, Cappuyns V et al (2013) Assessment on Pollution by Heavy Metals and Arsenic Based on Surficial and Core Sediments in the Cam River Mouth, Haiphong Province, Vietnam. Soil Sediment Contam 22:415-432. https://doi.org/10.1080/15320383.2013.733445

17. Hosono T, Su CC, Delinom R et al (2011) Decline in heavy metal contamination in marine sediments in Jakarta Bay, Indonesia due to increasing environmental regulations. Estuar Coast Shelf Sci 92:297-306.

https://doi.org/10.1016/j.ecss.2011.01.010

18. Hu Y, Liu X, Bai J et al (2013) Assessing heavy metal pollution in the surface soils of a region that had undergone three decades of intense industrialization and urbanization. Environ Sci Pollut Res 20:6150-6159.

https://doi.org/10.1007/s11356-013-1668-z

19. ISO (1998) Soil quality - Determination of organic carbon by sulfochromic oxidation.

https://www.iso.org/standard/23140.html

20. Liang J, Liu J, Xu G, Chen B (2019) Distribution and transport of heavy metals in surface sediments of the Zhejiang nearshore area, East China Sea: Sedimentary environmental effects. Mar Pollut Bull 146:542-551.

https://doi.org/10.1016/j.marpolbul.2019.07.001

21. Long ER, Macdonald DD, Smith SL, Calder FD (1995) Incidence of adverse biological effects within ranges of chemical concentrations in marine and estuarine sediments. Environ Manage 19:81-97. https://doi.org/10.1007/BF02472006

22. Loska K, Cebula J, Pelczar J et al (1997) Use of enrichment, and contamination factors together with geoaccumulation indexes to evaluate the content of $\mathrm{Cd}, \mathrm{Cu}$, and $\mathrm{Ni}$ in the Rybnik water reservoir in Poland. Water Air Soil Pollut 93:347365. https://doi.org/10.1007/BF02404766

23. Merhabi F (2021) Occurrence, distribution, and ecological risk assessment of emerging and legacy contaminants in the Kadicha river in Lebanon. https://doi.org/10.1007/s11356-021-15049-0

24. Muller G (1969) Index of geoaccumulation in sediments of the Rhine River. GeoJournal 2:108-118

25. Ngo TTH, Azadi H, Tran HC, Lebailly P (2018) Assessment of household risk management strategies for coastal aquaculture: the case of clam farming in Thaibinh Province, Vietnam. Aquac Int 26:451-468.

https://doi.org/10.1007/s10499-017-0226-y

26. Nguyen BT, Do DD, Nguyen TX et al (2020) Seasonal, spatial variation, and pollution sources of heavy metals in the sediment of the Saigon River, Vietnam. Environ Pollut 256:113412. https://doi.org/10.1016/j.envpol.2019.113412

27. Nour HES (2019) Distribution, ecological risk, and source analysis of heavy metals in recent beach sediments of Sharm El-Sheikh, Egypt. Environ Monit Assess 191:1-12. https://doi.org/10.1007/s10661-019-7728-1

28. OCME (2008) Guidelines for Identifying, Assessing and Managing Contaminated Sediments in Ontario. https://www.ontario.ca/document/guidelines-identifying-assessing-and-managing-contaminated-sediments-ontario

29. Phuong NM, Kang Y, Sakurai K et al (2010) Levels and chemical forms of heavy metals in soils from red river delta, Vietnam. Water Air Soil Pollut 207:319-332. https://doi.org/10.1007/s11270-009-0139-0

30. QCVN43:2017/BTNMT (2017) Vietnam National Technical Regulation. http://vea.gov.vn/Quy chun Vit Nam/QCVN 432017-BTNMT.pdf

Page 13/19 
31. Ranjbar Jafarabadi A, Riyahi Bakhtiari A, Spanò N, Cappello T (2018) First report of geochemical fractionation distribution, bioavailability and risk assessment of potentially toxic inorganic elements in sediments of coral reef Islands of the Persian Gulf, Iran. Mar Pollut Bull 137:185-197. https://doi.org/10.1016/j.marpolbul.2018.09.052

32. Robert LF (1980) Petrology of Sedimentary Rocks. Hemphill publishing company

33. Shilla D, Pajala G, Routh J et al (2019) Trophodynamics and biomagnification of trace metals in aquatic food webs: The case of Rufiji estuary in Tanzania. Appl Geochemistry 100:160-168.

https://doi.org/10.1016/j.apgeochem.2018.11.016

34. Tham TT, Bui, Lap Q et al (2021) Ecological Risk Assessment of Heavy Metals in Sediments of Duyen Hai Seaport Area in Tra Vinh Province. Vietnam Water Air Soil Pollut 232:1-11. https://doi.org/10.1007/s11270-021-05014-5

35. Tue NT, Quy TD, Amano A et al (2012) Historical profiles of trace element concentrations in Mangrove sediments from the Ba Lat Estuary, Red River, Vietnam. Water Air Soil Pollut 223:1315-1330. https://doi.org/10.1007/s11270-0110947-x

36. Turekian KK, Haven N, Hans K, Universitat WM Der (1961) KARL K. TUREKIAN Dept. Geology, Yale University, New Haven, Conn. KARL HANS WEDEPOHL Mineralogische-Institut der Universitat, Gottingen, Germany Distribution of the Elements in Some Major Units of the Earth's Crust. America (NY) 175-192

37. Tyson RV (1995) Abundance of Organic Matter in Sediments: TOC, Hydrodynamic Equivalence, Dilution and Flux Effects. Sediment Org Matter 81-118. https://doi.org/10.1007/978-94-011-0739-6_5

38. Vietnam Goverment Portal (2010) Red River with the evolutionary history of Vietnamese people. http://www.baochinhphu.vn/Utilities/PrintView.aspx?distributionid=30136

39. Wang SL, Xu XR, Sun YX et al (2013) Heavy metal pollution in coastal areas of South China: A review. Mar Pollut Bull 76:7-15. https://doi.org/10.1016/j.marpolbul.2013.08.025

40. Yang Y, Chen F, Zhang L et al (2012) Comprehensive assessment of heavy metal contamination in sediment of the Pearl River Estuary and adjacent shelf. Mar Pollut Bull 64:1947-1955.

https://doi.org/10.1016/j.marpolbul.2012.04.024

41. Ye Z, Chen J, Gao L et al (2020) 210Pb dating to investigate the historical variations and identification of different sources of heavy metal pollution in sediments of the Pearl River Estuary, Southern China. Mar Pollut Bull 150:110670. https://doi.org/10.1016/j.marpolbul.2019.110670

42. Youssef DH, El-Said GF (2011) Assessment of some heavy metals in surface sediments of the Aqaba Gulf, Egypt. Environ Monit Assess 180:229-242. https://doi.org/10.1007/s10661-010-1784-x

43. Zhu HN, Yuan XZ, Zeng GM et al (2012) Ecological risk assessment of heavy metals in sediments of Xiawan Port based on modified potential ecological risk index. Trans Nonferrous Met Soc China (English Ed 22:1470-1477. https://doi.org/10.1016/S1003-6326(11)61343-5

44. Zhuang W, Gao X (2015) Distributions, sources and ecological risk assessment of arsenic and mercury in the surface sediments of the southwestern coastal Laizhou Bay, Bohai Sea. Mar Pollut Bull 99:320-327.

https://doi.org/10.1016/j.marpolbul.2015.07.037

\section{Figures}




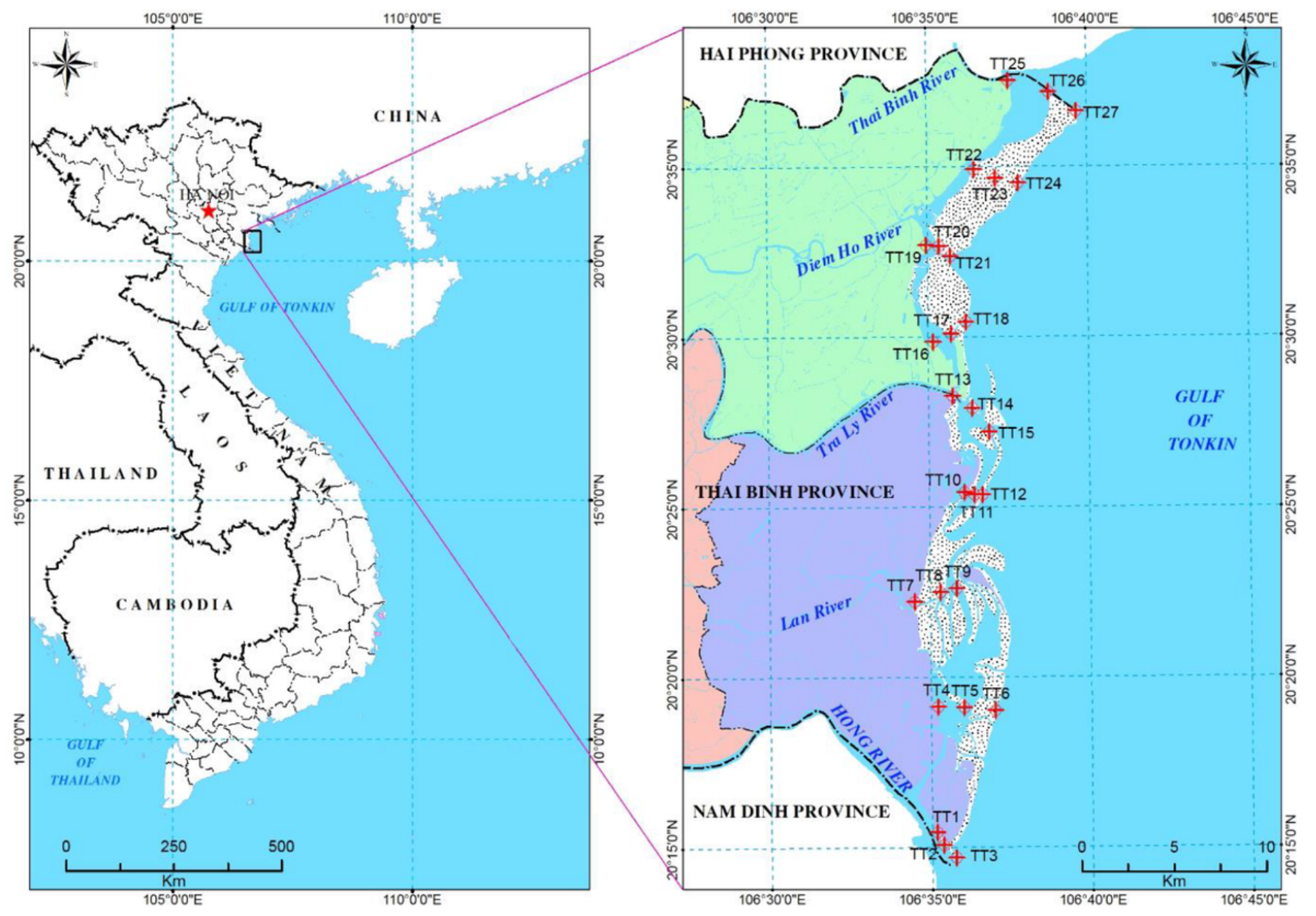

Figure 1

Sampling location along the Thai Binh coastal region and the insert map of Vietnam 


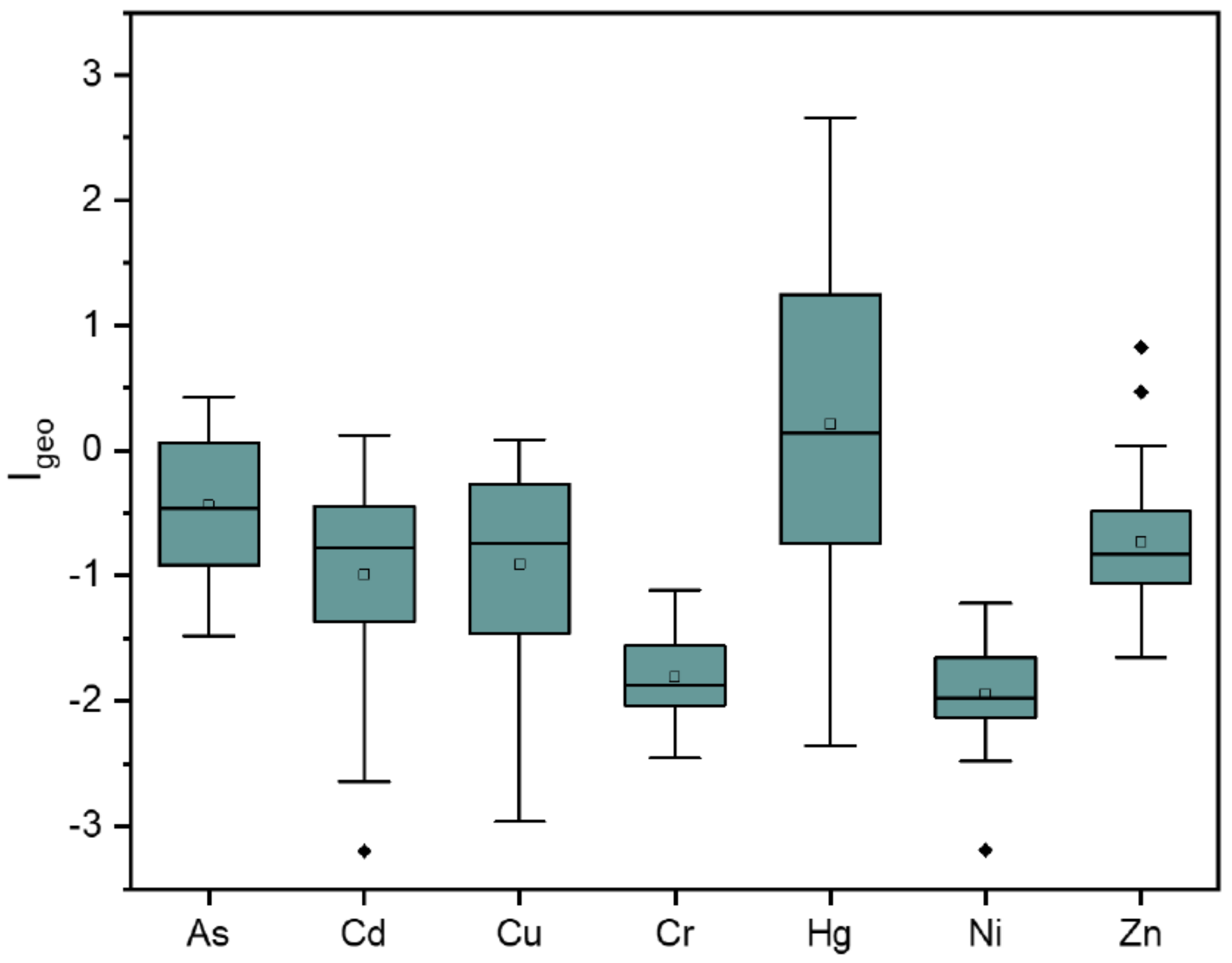

Figure 2

The box-and-whisker plot of Igeo 


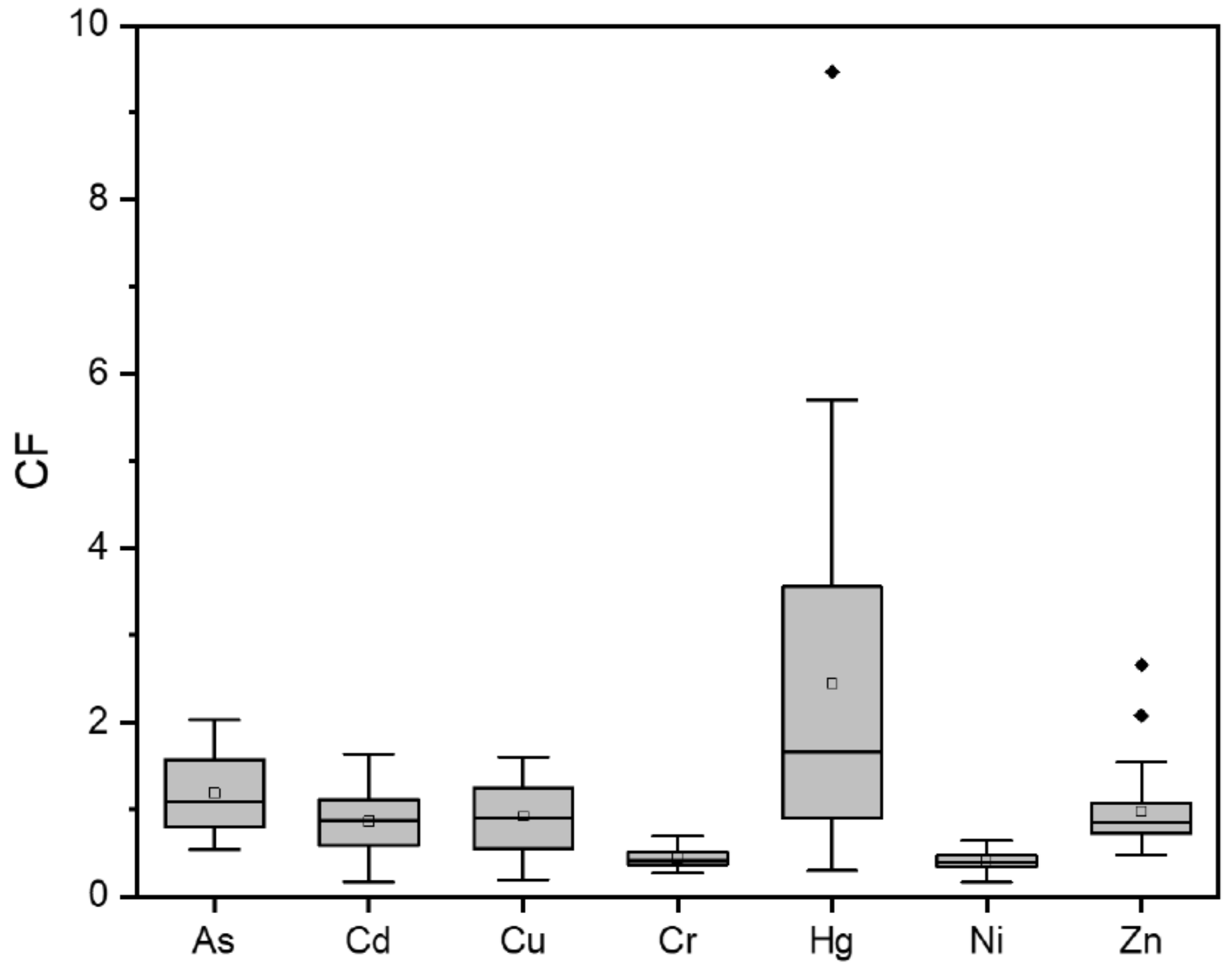

Figure 3

Box plot of the contamination factor of coastal surface sediments. 


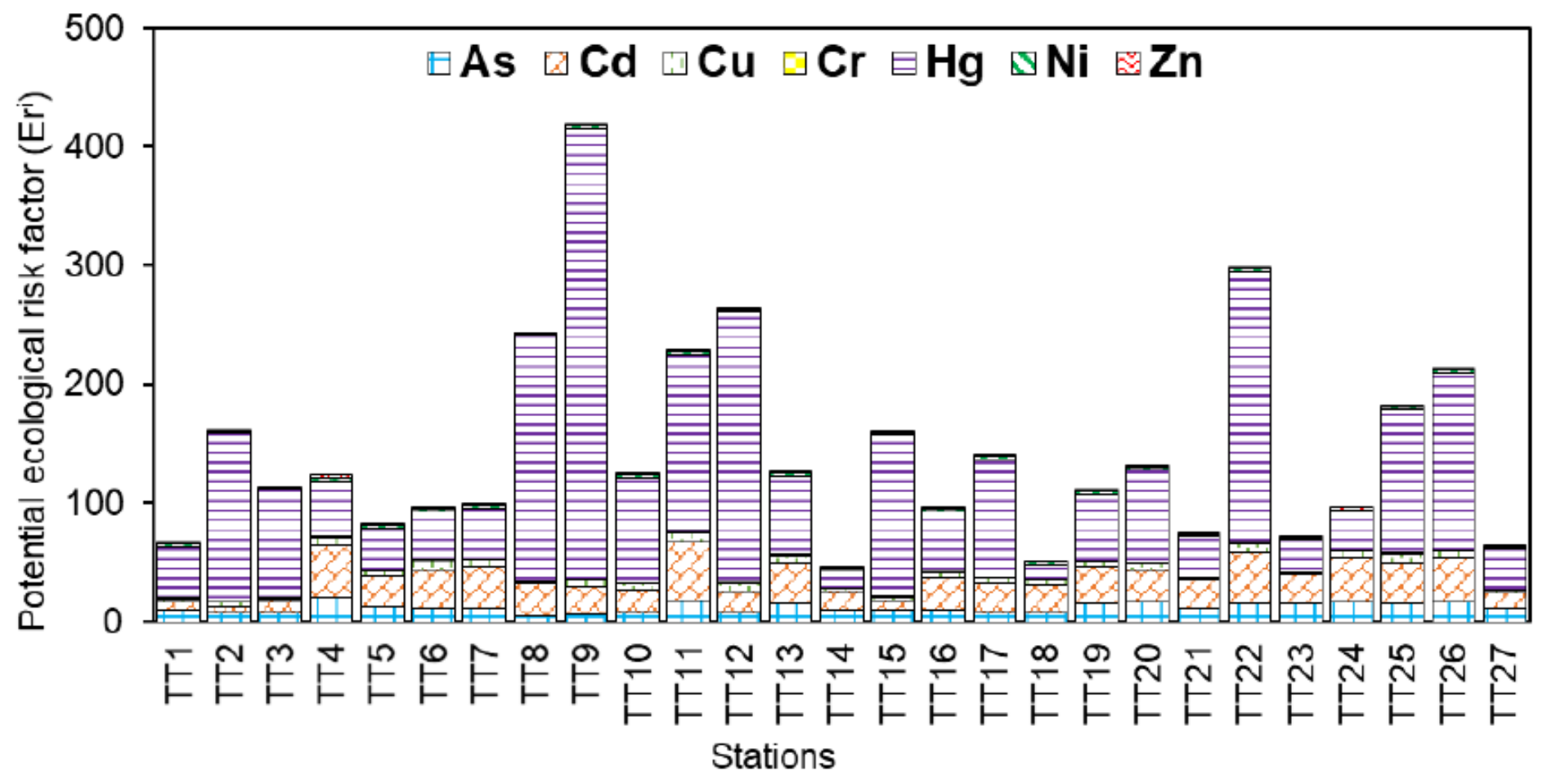

Figure 4

Ecological risk index of individual element Eri and potential ecological risk RI. TT1-TT24 represented the sample location on the map.

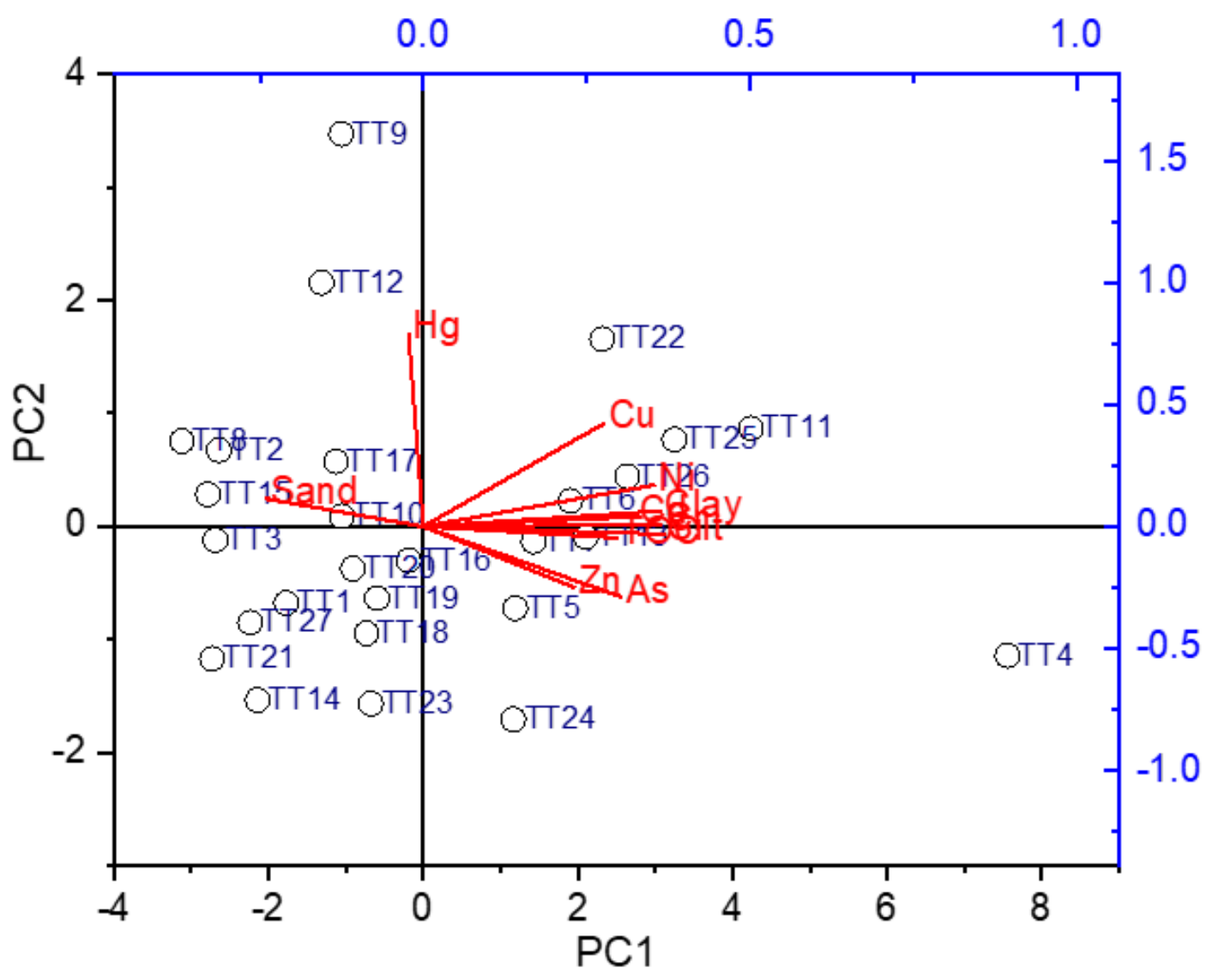

Figure 5 
Principal component analysis of heavy metals, TOC, clay, silt, and sand in the surface sediment in Thai Binh, Vietnam.

\section{Supplementary Files}

This is a list of supplementary files associated with this preprint. Click to download.

- SupplementalData.docx 